\title{
First record and evidence of an established population of the North American mud crab Dyspanopeus sayi (Brachyura: Heterotremata: Panopeidae) in the western Mediterranean
}

\author{
CHRISTOPH D. SCHUBART ${ }^{1}$, GUILLERMO GUERAO ${ }^{2}$ and PERE ABELLÓ ${ }^{3}$ \\ ${ }^{1}$ Biologie I, Universität Regensburg, D-93040 Regensburg, Germany. christoph.schubart@biologie.uni-regensburg.de \\ 2 IRTA, Unitat Operativa de Cultius Aqüàtics, Carretera Poble Nou, km 5.5, 43540 Sant Carles de la Ràpita, \\ Catalunya, Spain. \\ ${ }^{3}$ Institut de Ciències del Mar (CSIC), Passeig Marítim 37-49, 08003 Barcelona, Catalunya, Spain.
}

\begin{abstract}
SUMMARY: The panopeid crab Dyspanopeus sayi (Smith, 1869) is reported here from the Ebro Delta (Mediterranean coast of the Iberian Peninsula). Originally endemic to the Atlantic coast of North America, $D$. sayi was involuntarily introduced into Britain, France and the Netherlands, and into the Adriatic and Black Sea within the last thirty years. Here we provide the first record of this species from the western Mediterranean Sea. Occurrences of ovigerous females at different localities of the delta and in different years provide evidence that the population is well established. Mitochondrial DNA confirms the identity of the species and indicates that the introduced population consists of at least three female lineages. The first zoeal stage of D. sayi was obtained in the laboratory from an ovigerous female captured in August 2010 with embryos in an advanced stage of development. The morphology of the zoea I is described here in detail and is similar to the one previously reported for native populations.
\end{abstract}

Keywords: Dyspanopeus sayi, alien species, Mediterranean, Ebro Delta, mtDNA sequences, zoea.

RESUMEN: PRIMERA CITA Y EVIDENCIA DE UNA POBLACIÓN ESTABLECIDA DEL CANGREJO AMERICANO DYSPANOPEUS SAYI (Brachyura: Heterotremata: Panopeidae) en el Mediterráneo occidental. - Se informa de la presencia del cangrejo panopeido Dyspanopeus sayi (Smith, 1869) en el Delta del Ebro (costa mediterránea de la Península Ibérica). Originalmente endémica de la costa atlántica de América del Norte, D. sayi se introdujo en Gran Bretaña, Francia, los Países Bajos, en el Adriático y el Mar Negro en los últimos treinta años. En el presente trabajo se presenta el primer registro de esta especie en el Mediterráneo occidental. La presencia de hembras ovígeras en diferentes localidades del Delta del Ebro y en diferentes años evidencia que la población está bien establecida. El ADN mitocondrial confirma la identidad de la especie e indica que la población introducida consiste de por lo menos tres linajes de hembras. El primer estadio de zoea de $D$. sayi se obtuvo en el laboratorio a partir de una hembra ovígera capturada en agosto de 2010 , con embriones en una etapa avanzada de desarrollo. La morfología de la zoea I se describe en detalle, siendo similar a descripciones anteriores de poblaciones oriundas.

Palabras clave: Dyspanopeus sayi, especies invasoras, Mediterráneo, Delta del Ebro, secuencias de mtADN, zoea.

\section{INTRODUCTION}

Non-indigenous species represent potentially significant stressors in marine and estuarine communities (Ruiz et al. 1999). In addition to environmental concerns, alien species can also create serious economic and health impacts (Pimentel et al. 2005). The Medi- terranean Sea has been exceptionally susceptible to biological invasions, especially after the opening of the Suez Canal and the connection to the Indo-Pacific via the Red Sea (Galil et al. 2002). Among others, two species of Panopeidae have established large populations in estuarine habitats of the Mediterranean and Black Sea, namely Rhithropanopeus harrisii (Gould, 1841) 
(see Projecto-Garcia et al. 2010) and Dyspanopeus sayi (Smith, 1869).

Say's mud crab Dyspanopeus sayi is endemic to the northwestern Atlantic Ocean from Canada to Florida (Nizinski 2003). The species is most closely related to the second species and type of the genus, D. texanus (Stimpson, 1859), from the Gulf of Mexico. Dyspanopeus Martin and Abele, 1986 is the sister taxon to the genus Neopanope A. Milne-Edwards, 1880 (see Schubart et al. 2000), to which D. sayi and D. texanus used to belong before Martin and Abele (1986) placed them in their own genus. D. sayi is a euryhaline and eurythermic species inhabiting estuaries and shallow coastal marine waters from the intertidal to $46 \mathrm{~m}$ depth (Williams 1984). Within its native range, the mud crab is a common predator of shallow water bivalves (Strieb et al. 1995, Newell et al. 2007). Its larval development consists of four zoeal stages and one megalopa (Hyman 1925, Chamberlain 1961).

D. sayi was introduced into several localities of the northeastern Atlantic coast, southwestern Britain (Ingle 1980, Clark 1986), as well as more recently to the French and Dutch coast of the North Sea (Vaz et al. 2007). In the Mediterranean Sea, D. sayi has been collected from the Venice, Marano and Varano lagoons, as well as in the Po River Delta (western Adriatic Sea) (Froglia and Speranza 1993, Mizzan 1995, Florio et al. 2008) and more recently in the Black Sea (Micu et al. 2010). It was first reported in Venice Lagoon (Froglia and Speranza 1993) in 1992, but it must have been in the lagoon since the 1980s (Occhipinti Ambrogi 2000). Nowadays, it is the most common crab in this lagoon, exceeding in abundance the native species Carcinus aestuarii and Pilumnus hirtellus forma aestuarii (see Mizzan 1995, Schubart pers. observ. 2006).

In the present paper, the presence of Dyspanopeus sayi is documented from Alfacs Bay (Ebro Delta, Tarragona, Spain). This is the first record of the species from the western Mediterranean (compare with Galil et al. 2002). In addition, mitochondrial DNA of three individuals of this population was compared with the DNA from two conspecifics from Venice Lagoon and with the one from selected individuals from the native range of this species. The morphology of the first zoeal stage was described in detail and compared with previous descriptions of this species.

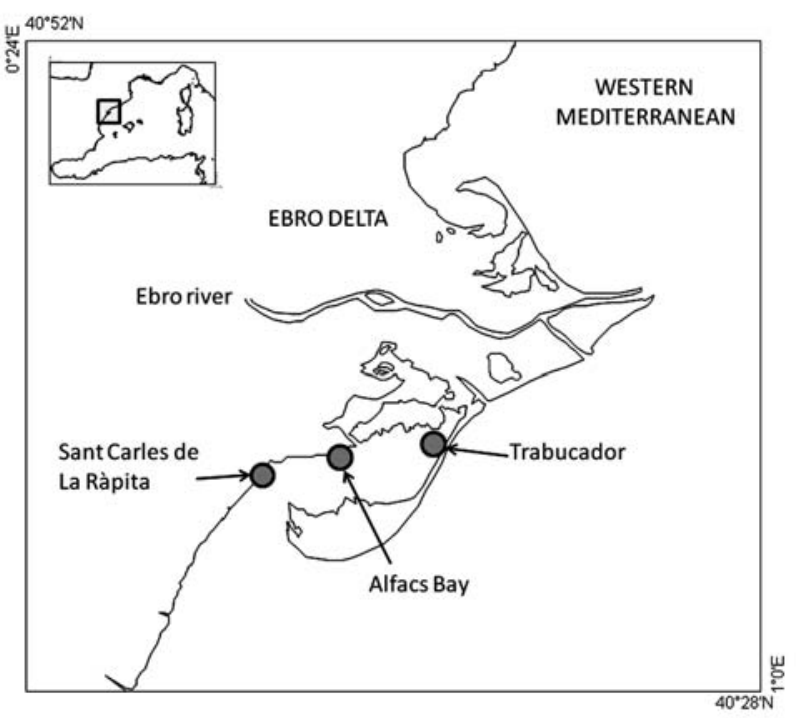

FIG. 1. - Location of the reported records of the exotic crab Dyspanopeus sayi in the Ebro Delta (western Mediterranean).

\section{MATERIALS AND METHODS}

Adult specimens of Dyspanopeus sayi were collected by hand and small beam trawls (see Fusté 1988 ) in Alfacs Bay, Ebro Delta (4040’ N; 040’E), located on the northeast Spanish Mediterranean coast (Catalonia: Tarragona) (Fig. 1) in November 2005, September 2006, and August 2010 (Table 1). Sampling depth ranged from 0.5 to $1.5 \mathrm{~m}$. The samples from 2005 and 2006 were collected by hand (partly snorkelling) from pillars covered in green algae, either in the port of Sant Carles de la Ràpita or at the landward edge of the sandy spit El Trabucador. Specimens from 2010 were collected by beam trawls from sandymuddy bottoms of Alfacs Bay covered by the seagrass Cymodocea nodosa and the alga Caulerpa prolifera (see Pérez and Camp 1986). Alfacs Bay is a shallow semi-enclosed estuary (3 m mean depth) at the south side of the Ebro River Delta complex, from which it receives freshwater from March/April to October/November, through discharge channels that flow out onto its northern shelf (Camp and Delgado 1987, Solé et al. 2009). The bay is separated from the Mediterranean

TABLE 1. - Specimens of Dyspanopeus sayi (Smith, 1869) collected from the Ebro Delta.

\begin{tabular}{lccccc}
\hline Collection locality & specimens & CW $(\mathrm{mm})$ & CL $(\mathrm{mm})$ & Date & Collectors \\
\hline El Trabucador & \multicolumn{1}{c}{${ }^{2}$} & 14.7 & 12.3 & 8.Nov.2005 & CD Schubart, F Gmeiner and P Abelló \\
El Trabucador & 0 & 12.1 & 9.4 & 8.Sept.2006 & CD Schubart, S Reuschel and L Ragionieri \\
Sant Carles de la Ràpita, harbour & ov. & 12.8 & 10.5 & 9.Sept.2006 & CD Schubart, S Reuschel and L Ragionieri \\
Alfacs Bay & + & 17.4 & 13.6 & 9. Aug. 2010 & G Guerao \\
Alfacs Bay & ov. & 15.7 & 12.4 & 24.Aug.2010 & G Guerao \\
Alfacs Bay & 0 & 26.3 & 19.1 & 24.Aug.2010 & G Guerao \\
Alfacs Bay & 0 & 20.5 & 15.4 & 24.Aug. 2010 & G Guerao \\
Alfacs Bay & 0 & 19.1 & 13.9 & 24.Aug.20 10 & G Guerao \\
Alfacs Bay & 0 & 22.1 & 15.9 & 09. Aug.2010 & G Guerao \\
Alfacs Bay & 0 & 22.9 & 17.1 & 09. Aug.2010 & G Guerao \\
\hline
\end{tabular}


TABLE 2. - Origin of specimens of Dyspanopeus sayi (Smith, 1869) used for genetic analyses and comparison of 658 basepairs of the mitochondrial Cox 1 gene. Specimens from Canada from Radulovici et al. (2009) (RMNH: Naturalis Museum, Leiden; SMF: Senckenberg Museum und Forschungsinstitut, Frankfurt; ULLZ: University of Louisiana at Lafayette Zoological Collection, Lafayette; USNM: National Museum of Natural History of the Smithsonian Institution, Washington DC).

\begin{tabular}{|c|c|c|}
\hline Collection Locality and Date & voucher \# & accession \# \\
\hline Canada (Prince Edward Island): 46.052N 63.039W, 2. Aug. 2008 & L228AR1-02 & FJ581617 \\
\hline Canada (New Brunswick): St. Lawrence Bay: 46.516N 64.684W, 5. Aug. 2007 & L183AR1-01 & FJ581619 \\
\hline Canada (New Brunswick): St. Lawrence Bay: 46.224 N 64.553 W, 24. July 2007 & L154AR1-06 & FJ581619 \\
\hline USA (Florida): Fort Pierce; 18. March 1998 & ULLZ 3752 & FR869685 \\
\hline USA (Massachusetts): Boston: Watertown; 18. June 2006 (2 individuals) & USNM 1154253 & FR869687 \\
\hline Spain: Ebro Delta: El Trabucador; 8. Nov. 2005: 40³7,712’N-044,470’W & RMNH-D.53427 & FR869685 \\
\hline Spain: Ebro Delta: El Trabucador; 8. Sept. 2006: 40³7,712’N-044,470’W & SMF-38945 & FR869684 \\
\hline Spain: Ebro Delta: St. Carles de la Ràpita; 9. Sept. 2006 & SMF-38944 & FR869686 \\
\hline Italia (Veneto): Venice Lagoon: Fusina; 11. Aug. 2006 (2 individuals) & USNM 1154252 & FR869688 \\
\hline
\end{tabular}

Sea by a $5 \mathrm{~km}$ long, $300 \mathrm{~m}$ wide sandbar that forms a $2.5 \mathrm{~km}$ wide embayment (Camp 1994). The habitat mostly consists of sandy bottoms and seagrass meadows. Crab samples were measured and conserved in 70-95\% ethanol. Collected individuals were identified as Dyspanopeus sayi in accordance with Williams (1984) and Martin and Abele (1986). Specimens were deposited at the Biological Collections of Reference of the Institut de Ciències del Mar (CSIC) in Barcelona, under the accession code ICMD_20110201_01 and at the Naturalis Museum, Leiden; Senckenberg Museum und Forschungsinstitut, Frankfurt; University of Louisiana at Lafayette Zoological Collection, Lafayette; National Museum of Natural History of the Smithsonian Institution, Washington DC (see Table 2 for collection numbers).

From a total of eight individuals (see Table 2 for localities) DNA was extracted from the muscle tissue of a walking leg and DNA isolation was performed with a modified Puregene method from Gentra Systems. DNA pellets were resuspended in $20 \mu \mathrm{l}$ TE buffer and the concentration was ascertained on agarose gels. From the corresponding dilutions of the DNA solution, $1 \mu l$ was used for polymerase chain reactions. 658 basepairs of the mitochondrial cytochrome subunit 1 (Cox1) region were amplified with the primer combination COL6b (ACA AAT CAT AAA GAT ATY GG) and COH6 (TAD ACT TCD GGR TGD CCA AAR AAY CA) (see Schubart and Huber 2006) in PCR with a standard $25 \mu \mathrm{l}$ reaction containing $2.5 \mu \mathrm{l}$ of $10 \mathrm{x}$ buffer, $2.5 \mu \mathrm{l}$ of $1.25 \mathrm{mM}$ dNTPs, $0.5 \mu \mathrm{l}$ of both primers $(20 \mathrm{mM}), 2 \mu \mathrm{l}$ of $25 \mathrm{mM} \mathrm{MgCl} 2,1 \mu \mathrm{l}$ of $0.5 \mathrm{U} / \mu \mathrm{l} \mathrm{TAQ}$, $15 \mu \mathrm{l}$ of double-distilled water, and $1 \mu \mathrm{l}$ target DNA. 40 cycles were run at an annealing temperature of $48^{\circ} \mathrm{C}$. PCR products were cleaned using SureClean (Bioline) and sequenced with an ABI-PRISM 310 (Applied Biosystems, Carlsbad CA). Sequences were aligned by eye (no indels) together with three sequences from Genbank originating from conspecific individuals from the Gulf of St. Lawrence, Canada (FJ581617-FJ581619, Radulovici et al. 2009). The alignment was converted into a nexus file to construct a statistical parsimony network as implemented in the TCS software package version 1.21 (Clement et al. 2000). The corresponding network was then redrawn by hand.
One captured ovigerous female was kept in an aquarium $(40 \times 20 \times 15 \mathrm{~cm})$ containing well-aerated, filtered seawater at a salinity of 34 and temperature of $18 \pm 1^{\circ} \mathrm{C}$. The larvae hatched on the following day and were preserved in $70 \%$ ethanol for morphological and morphometric studies. An Olympus BH-2 microscope was used to observe the setal formula of the appendages. Measurements of 20 individuals were taken with a Nikon SMZ800 stereo microscope equipped with an image analysing system (AnalySIS, SIS, Münster, Germany). The following measurements were taken: distance from the tip of the rostral spine to the tip of the dorsal spine (RDL); carapace length between eyes (base of the rostrum) to the posterolateral carapace margin (CL); carapace width as the distance between the tips of lateral spines $(\mathrm{CW})$; rostral spine length, from base of eye to tip of rostral spine (RL); antenna length, from base of eye to tip of spinous process (AL). A total of 20 first zoeae was deposited in the Biological Collections of Reference of the Institut de Ciències del Mar (CSIC) in Barcelona under accession code ICMD 20110201 02.

\section{RESULTS}

Dyspanopeus sayi (Fig. 2) was identified in samples from shallow areas with a total number of 14 specimens including two ovigerous females (Table 1). Comparison of the DNA of the mitochondrial gene Cox1 of three individuals from the Ebro Delta with three sequences from St. Lawrence Bay (New Brunswick, Canada), two from Boston (Massachusetts, USA), one from Fort Pierce (Florida, USA) and two from Venice Lagoon (Italy) confirmed the species identity and gave the first indications of haplotype richness in the native as well as in the introduced populations (Fig. 3). While three animals from New Brunswick were genetically identical, those from Boston, Venice and the Ebro Delta showed distinct haplotypes between the two or three individuals sampled.

Larvae hatched at night from a single female (Fig. 4). No larva reached the second zoeal stage. Measurements of zoeal morphology and setal formulae of cephalothoracic appendages are listed in Table 3. The first zoea has the following main features: 1) Carapace 


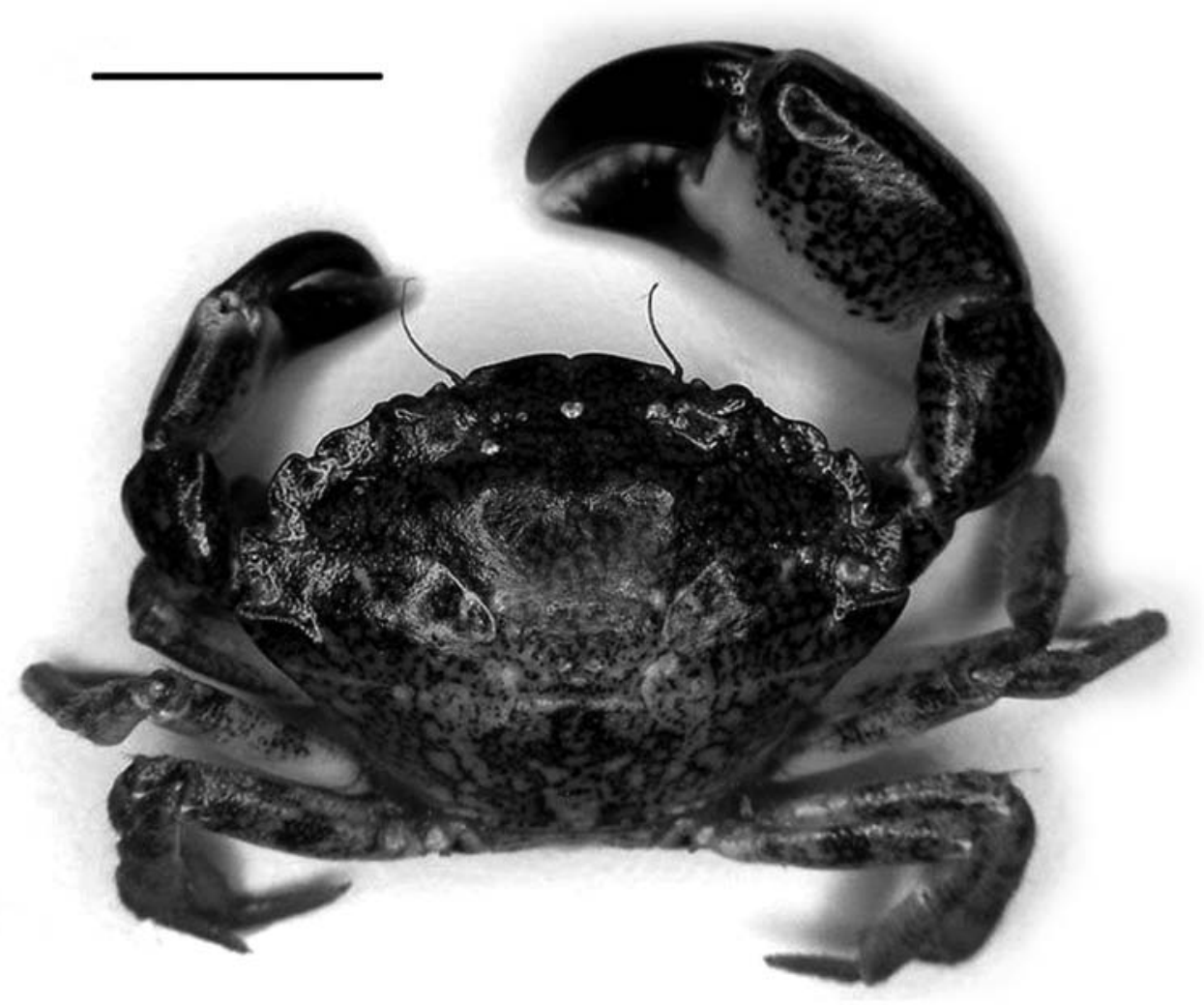

FIG. 2. - Dyspanopeus sayi. Adult specimen from Alfacs Bay (male; ICMD_20110201_01). Scale bar 10 mm.

with rostral, lateral and dorsal spines; length of rostral spine 1.5 times carapace length and similar in length to dorsal spine. 2) Antennal protopodal process without spinulation, longer than rostral spine; exopod minute, with one terminal seta. 3) Pleon with five somites; somites 2 and 3 with one pair of dorsolateral processes;

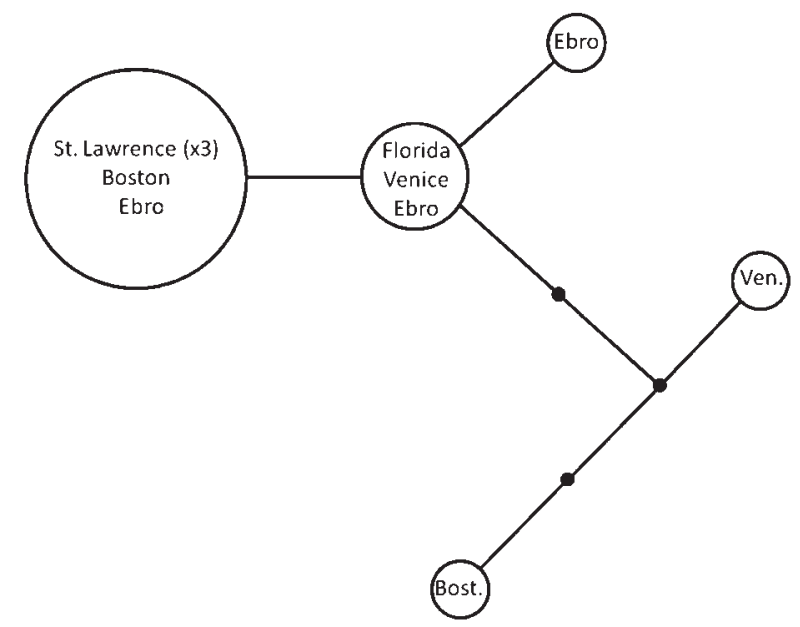

FIG. 3. - Haplotype network of eleven specimens of Dyspanopeus sayi from introduced Mediterranean as well as from native populations. The network is based on 658 basepairs of the Cox 1 mtDNA. Population localities are written within haplotypes (Ven., Venice Lagoon; Bost., Boston). somites 3-5 with posterolateral similar-sized processes; somites 2-5 each with one pair of posterodorsal setae. 4) Telson with long non-spinulated fork; with one dorsomedian spine on each furcal arm and three pairs of stout spinulate setae on posterior margin.

\section{DISCUSSION}

The carapace widths $(\mathrm{CW})$ of individuals captured in Alfacs Bay (males 12.1-26.3 mm, N=6; females 12.8-17.4 mm, $\mathrm{N}=4$ ) are slightly smaller than those reported for the Black Sea population (15.4-28.8 mm for males and 12.0-19.3 mm for females respectively, Micu et al. 2010). In its native range Dyspanopeus sayi can attain a maximum size of $30 \mathrm{~mm} \mathrm{CW}$ (Williams 1984, Strieb et al. 1995).

Two ovigerous females were collected, one in September 2006 (CW $12.8 \mathrm{~mm}$ ) and one in August 2010 $(\mathrm{CW} 15.7 \mathrm{~mm})$, which agrees with the reproductive seasonality in its native habitat: Dittel and Epifanio (1982) collected larvae of D. sayi from June to October in Delaware Bay. In the Adriatic and Black Sea, ovigerous females have been observed in September and from September to October respectively (Mizzan 1995, Micu et al. 2010).

The meristic and morphometric characteristics of the first zoeal stage of Dyspanopeus sayi are shown in Table 3. The morphology of the larvae agrees well with 


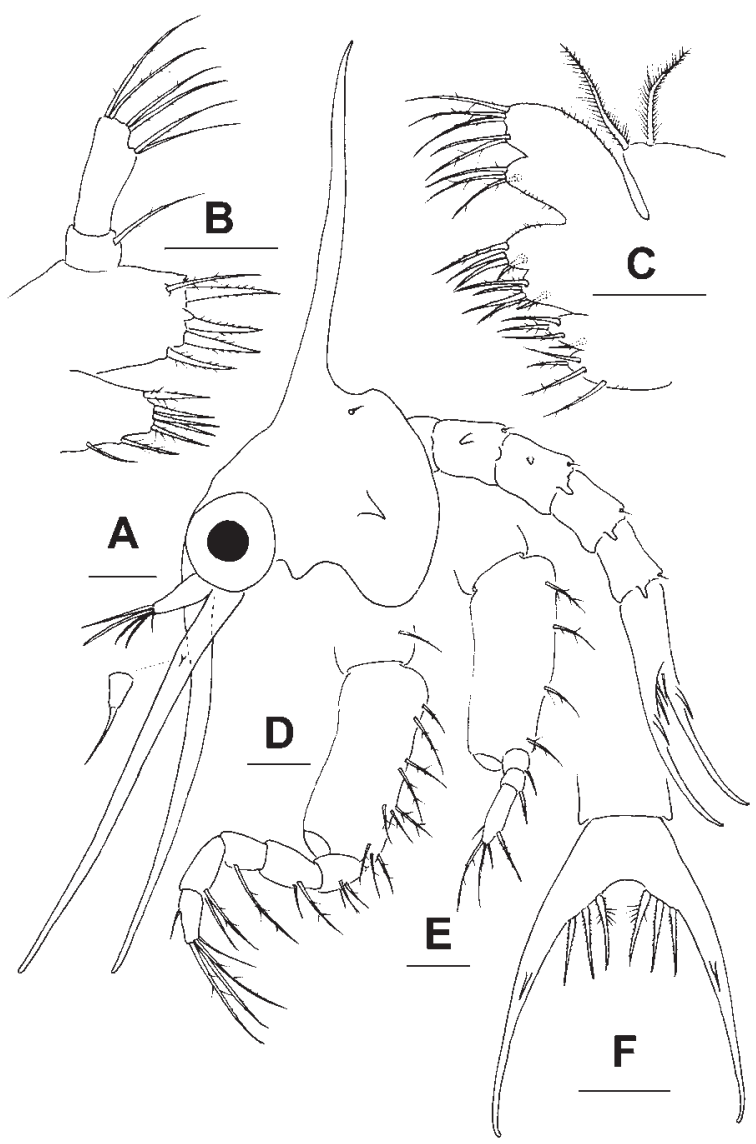

FIG. 4. - Dyspanopeus sayi. First zoea. Lateral view (A); maxillule (B); maxilla, endites and endopod (C); first maxilliped, exopod omitted (D); second maxilliped, exopod omitted (E); Telson, dorsal view (F). Scale bar of A and F: $100 \mu \mathrm{m}$; of B-E: $50 \mu \mathrm{m}$. previous descriptions of the larval morphology from North American populations (Chamberlain 1961, Clark 2007). However, measurements cannot be compared, except for the rostro-dorsal length (RDL). The larvae of the Ebro Delta have clearly larger RDL values than the ones measured by Chamberlain (1961). The description of Clark (2007) does not provide biometric information in the text. However, the figures show shorter dorsal and rostral spines than those of the present description, which therefore suggests a smaller RDL. However, more biometric studies are necessary to reach conclusions about differences in the size of the Mediterranean larvae.

$D$. sayi has a planktonic larval development with four zoeal stages plus megalopa (Chamberlain 1961). The larval phase constitutes the dispersive stage, and is thus the crucial stage for invading crustacean species with extended development in order to establish themselves and persist in new locations as well as extend the range of new populations. Nevertheless, it is unlikely, if not impossible, that Dyspanopeus sayi was introduced naturally from North America or Britain into the western Mediterranean due to their planktonic larval duration and the present pattern of oceanographic currents and geographic barriers. Also the Italian Peninsula constitutes an important natural barrier which would largely restrict gene flow from the Adriatic to the western Mediterranean. Adult D. sayi do not migrate seasonally between the coast and deeper waters; the movements of the adults are local (Micu et al. 2010). We therefore propose a new human-mediated introduction of this species into the Ebro Delta, unless other, geographically intermediate populations are discovered.

TABLE 3. - Dyspanopeus sayi (Smith, 1869). Morphological and biometric characteristics of first zoea. Abbreviations: a, aesthetascs, AL, antenna length (protopod process); CL, carapace length; cox, coxa; mxpd, maxilliped; pd, posterodorsal; RDL, rostrodorsal length; RL, rostral spine length; s, setae; CW, carapace width; * described from figure.

\begin{tabular}{|c|c|c|c|}
\hline Feature & $\begin{array}{c}\text { Present study } \\
\text { W Mediterranean }\end{array}$ & $\begin{array}{c}\text { Chamberlain (1961) } \\
\text { Chesapeake (E Atlantic) }\end{array}$ & $\begin{array}{c}\text { Clark (2007) } \\
\text { Florida (E Atlantic) }\end{array}$ \\
\hline $\operatorname{RDL}(\mu \mathrm{m})$ & $1863.5 \pm 12.4$ & 1200 & - \\
\hline CL $(\mu \mathrm{m})$ & $514.4 \pm 31.9$ & - & - \\
\hline $\mathrm{CW}(\mu \mathrm{m})$ & $612.5 \pm 31.5$ & - & - \\
\hline $\mathrm{RL}(\mu \mathrm{m})$ & $786.0 \pm 12.2$ & - & - \\
\hline $\mathrm{AL}(\mu \mathrm{m})$ & $832.3 \pm 50.0$ & - & - \\
\hline Carapace (s) & $2 \mathrm{pd}$ & 0 & $2 \mathrm{pd}$ \\
\hline Antennula $(a+s)$ & $4+1$ & $3-4$ & $4+1$ \\
\hline \multicolumn{4}{|l|}{ Maxillule } \\
\hline coxal end (s) & 7 & 6 & 7 \\
\hline basial end (s) & 5 & 5 & 5 \\
\hline endopod (s) & $1+6$ & $1+6$ & $1+6$ \\
\hline \multicolumn{4}{|l|}{ Maxilla } \\
\hline coxal end (s) & $4+4$ & $5-8$ & $4+4$ \\
\hline basial end (s) & $5+4$ & $5-9$ & $5+4$ \\
\hline endopod (s) & $3+5$ & $7-8$ & $3+5$ \\
\hline \multicolumn{4}{|l|}{ First maxilliped } \\
\hline coxa $(\mathrm{s})$ & 1 & 1 & $1 *$ \\
\hline basis (s) & $2+2+3+3$ & $2+2+3+3$ & $2+2+3+3$ \\
\hline endopod (s) & $3,2,1,2,5$ & $2-3,2,1,1-2,4-5$ & $3,2,1,2,5$ \\
\hline exopod (s) & 4 & 4 & 4 \\
\hline \multicolumn{4}{|l|}{ Second maxilliped } \\
\hline $\operatorname{coxa}(\mathrm{s})$ & 0 & 0 & 0 \\
\hline basis ( $\mathrm{s}$ ) & 4 & 4 & 4 \\
\hline endopod (s) & $1,1,5$ & $1,1,4-5$ & $1,1,5$ \\
\hline exopod (s) & 4 & 4 & 4 \\
\hline
\end{tabular}


The genetic results of four different haplotypes found in the five analyzed individuals from introduced populations (two from Venice Lagoon and three from Ebro Delta, one of which is shared) argue against colonization events based on single female lineages in both populations and suggest that the European populations do not have strong genetic bottlenecks. This has also been shown for the second introduced panopeid crab in Europe, Rhithropanopeus harrisii (see Projecto-Garcia et al. 2010).

Commercial and non-commercial vessels are both important vectors for secondary introduction and dispersal of alien species beyond their primary location of introduction (Cannicci et al. 2006). Studies show that 188 metazoan species have been introduced into the Mediterranean by vessels and that the number is steadily rising. Secondary dispersion by vessels within the Mediterranean Sea is also an important issue (IUCN 2009). Decapod crustaceans are often introduced in connection with commercial maritime traffic, since their larvae can survive long periods in ballast water (Occhipinti Ambrogi 2000). Movements and exchanges of aquaculture products (i.e. bivalve seed production, commercialization of live bivalve and crustaceans) may also be a source of introduction of non-native species.

Each human-mediated introduction raises the question of the potential impact to be expected from this new member in the biological community. Predation by non-native crabs is thought to be the cause of dramatic declines in the number of clams Mya arenaria in northern New England and southeastern Canada (Cohen et al. 1995). Predation by a panopeid mud crab on the American oyster Crassostrea virginica (see Bisker and Castagna 1987) and the hard clam Mercenaria mercenaria (see Whetstone and Eversole 1981) received considerable attention due to the economic implications for commercial harvests. Dyspanopeus sayi is a molluscivorous crab, its main prey organisms being bivalve molluscs and barnacles. Its predator activities take place at dusk or in darkness. It uses its major chela to break open the shell of its prey (Mistri 2004). In the Adriatic Sea, D. sayi has exterminated prey species like Mytilus galloprovincialis, Mytilaster lineatus, Ostrea edulis and Crassostrea gigas in a very small locally restricted area (Mizzan 1998). Alfacs Bay is very important for the economy of the region due to its fish and shellfish farming and aquaculture. The mollusc species of commercial value of this area are Mytilus galloprovincialis, Crassostrea gigas, Ruditapes decussatus and $R$. philippinarum (see Ramón et al. 2005). The most abundant epibenthic predator is Carcinus aestuarii (see Fusté 1988). This carcinid crab is an important predator that may control the local abundance and distribution of populations of its benthic prey (Richards et al. 1999). However, in the Ebro Delta, the predatory behaviour of $C$. aestuarii, like many other aspects of its biology, is currently unknown. Thus, biological and ecological studies are necessary as soon as possible in order to assess the real impact that Dyspanopeus sayi can have on the Ebro Delta system.

\section{ACKNOWLEDGEMENTS}

Travel funds to CDS and students were made possible through an exchange program of the DAAD (D/03/40344) and the Spanish Ministerio de Ciencia y Tecnología - Acciones Integradas (HA2003-078), with José A. Cuesta as Spanish collaborator. Florian Gmeiner, Silke Reuschel and Lapo Ragionieri assisted during field collections in 2005 and 2006 respectively and students at the University of Regensburg helped with the molecular work. Financial support to GG (post-doctoral fellowship; INIA) was provided by the Ministry of Science and Research. The authors would like to thank Agustí Benito, fisherman of Sant Carles de la Ràpita for his collaboration in catching crabs. PA acknowledges research project CGL2009-12912-C03-03 from the Ministerio de Ciencia e Innovación (Spain). Paul Clark kindly made available important literature and shared his own unpublished description of the first zoeal stage of Dyspanopeus sayi.

\section{REFERENCES}

Bisker R., Castagna M. 1987. Predation on single spat oysters Crassostrea virginica (Gmelin) by blue crabs Callinectes sapidus Rathburn and mud crabs Panopeus herbstii Milne-Edwards. J. Shellfish Res. 6: 37-40.

Camp J. 1994. Aproximaciones a la dinámica ecológica de una bahía estuárica mediterránea. Ph.D. Thesis, Univ. Barcelona, 245 pp.

Camp J., Delgado M. 1987. Hidrografía de las bahas del Delta del Ebro. Inv. Pesq. 51: 351-359.

Cannicci S., Garcia L., Galil B.S. 2006. Racing across the Mediterranean-first record of Percnon gibbesi (Crustacea: Decapoda: Grapsidae) in Greece. Mar. Biodiversity Rec. 1(e32): 1-2.

Chamberlain N.A. 1961. Studies on the larval development of $\mathrm{Ne}$ opane texana say (Smith) and other crabs of the family Xanthidae (Brachiura). Chesapeake Bay Institute, The Johns Hopkins Univ. Tech. Rep., 22: 1-35.

Clark P.F. 1986. North-east Atlantic crabs; an atlas of distribution. Marine Conservation Society, Ross-on-Wye, 252 pp.

Clark P.F. 2007. Xanthoid crab (Crustacea: Decapoda: Brachyura) classification and phylogeny: an appraisal using the chaetotaxy of first stage zoeae. Ph.D. Thesis, Univ. London, 473 pp.

Clement M., Posada D., Crandall K. 2000. TCS: a computer program to estimate gene genealogies. Mol. Ecol. 9: 1657-1660.

Cohen A.N., Carlton J.T., Fountain M.C. 1995. Introduction, dispersal and potential impact of the green crab Carcinus maenas in San Francisco Bay, California. Mar. Biol. 122: 225-237.

Dittel A.I.R., Epifanio C.E. 1982. Seasonal abundance and vertical distribution of crab larvae in Delaware Bay. Estuaries 5: 197-202.

Florio M., Breber P., Scirocco T., Specchiulli A., Cilenti L., Lumare L. 2008. Exotic species in Lesina and Varano lakes: Gargano National Park (Italy). Transit. Waters Bull. 2: 69-79.

Froglia C., Speranza S. 1993. First records of Dyspanopeus sayi (Smith, 1869) in the Mediterranean Sea (Crustacea: Decapoda: Xanthidae). Ouad. Ist. Ricerca Pesca Marit. 5: 163-166.

Fusté X. 1988. Crustáceos decápodos de la Bahía de els Alfacs (Delta del Ebro). Inv. Pesq. 52: 617-623.

Galil B.S., Froglia C., Noël. P. 2002. CIESM Atlas of exotic species in the Mediterranean. 2. Crustaceans. CIESM Publishers, Monaco, $192 \mathrm{pp}$.

Hyman O.W. 1925. Studies on the larvae of crabs of the family Xanthidae. Proc. U.S. Nat. Mus. 67(3): 1-22.

Ingle R.W. 1980. British crabs. Oxford University Press, London and New York, 222 pp. 
IUCN. 2009. Risks from maritime traffic to biodiversity in the Mediterranean Sea: Identification of issues and possible responses. IUCN - Centre for Mediterranean Cooperation, Málaga, $26 \mathrm{pp}$.

Martin J.W., Abele L.G. 1986. Notes on male pleopod morphology in the brachyuran crab family Panopeidae Ortmann, 1893 sensu Guinot (1978) (Decapoda). Crustaceana, 50: 182-198.

Micu D., Victor N., Todorova V. 2010. First record of Say's mud crab Dyspanopeus sayi (Brachyura: Xanthoidea: Panopeidae) from the Black Sea. Mar. Biodiversity Rec. 3: 1-6.

Mistri M. 2004. Predatory behavior and preference of a successful invader, the mud crab Dyspanopeus sayi (Panopeidae), on its bivalve prey. J. Exp. Mar. Biol. Ecol. 312: 385-398.

Mizzan L. 1995. Notes on presence and diffusion of Dyspanopeus sayi in the Venetian Lagoon. Boll. Mus. Civ. Stor. Nat. Venezia 44: 121-129.

Mizzan L. 1998. Caratteristiche ecologiche e popolazionali di alcuni biotopi particolari (pozze di sifonamento) a Lido di Venezia. Boll. Mus. Civ. Stor. Nat. Venezia 48: 183-192.

Newell R.I.E., Kennedy V.S., Shaw K.S. 2007. Comparative vulnerability to predators, and induced defense responses, of eastern oysters Crassostrea virginica and non-native Crassostrea ariakensis oysters in Chesapeake Bay. Mar. Biol. 152: 449-460.

Nizinski M.S. 2003. Annotated checklist of decapod custaceans of Atlantic coastal and shelf waters of the United States. Proc Biol. Soc. Wash. 116: 96-157.

Occhipinti Ambrogi A. 2000. Biotic invasions in a Mediterranean Lagoon. Biol. Invas. 2: 165-176.

Pérez M., Camp J. 1986. Distribución espacial y biomasa de las fanerógamas marinas de las bahías del delta del Ebro. Inv. Pesq. 50: $519-530$

Pimentel D., Zuniga R., Morrison D. 2005. Update on the environmental and economic costs associated with alien invasive species in the United States. Ecol. Econom. 52: 273-288.

Projecto-Garcia J., Cabral H., Schubart C.D. 2010. High regional differentiation in a North American crab species throughout its native range and invaded European waters: a phylogeographic analysis. Biol. Invas. 12: 253-263.

Radulovici A.E., Sainte-Marie B., Dufresne F. 2009. DNA barcoding of marine crustaceans from the Estuary and Gulf of St Lawrence: a regional-scale approach. Mol. Ecol. Resour. 9-S1: 181-187.

Ramón M., Cano J., Peña J.B., Campos M.J. 2005. Current status and perpectives of mollusc (bivalves and gastropods) culture in the Spanish Mediterranean. Bol. Inst. Esp. Oceanogr. 21(1-4): 361- 373.

Richards M.G., Huxham M., Bryant A. 1999. Predation: a causal mechanism for variability in intertidal bivalve populations. $J$. Exp. Mar. Biol. Ecol. 241: 159-177.

Ruiz G.M., Fofonoff P., Hines A.H., Grosholz E.D. 1999. Nonindigenous species as stressors in estuarine and marine communities: assessing invasion impacts and interactions. Limnol. Oceanogr. 44: 950-972.

Schubart C.D., Huber M.G.J. 2006. Genetic comparisons of German populations of the stone crayfish, Austropotamobius torrentium (Crustacea: Astacidae). Bull. Franç. Pêche Piscic. 380-381: 1019-1028.

Schubart C.D., Neigel J.E., Felder D.L. 2000. A molecular phylogeny of mud crabs (Brachyura: Panopeidae) from the northwestern Atlantic and the role of morphological stasis and convergence. Mar. Biol. 137: 11-18.

Solé J., Turiel A., Estrada M., Llebot C., Blasco D., Camp J., Delgado M, Fernández-Tejedor M., Diógene J. 2009. Climatic forcing on hydrography of a Mediterranean bay (Alfacs Bay). Continent. Shelf Res. 29: 1786-1800.

Strieb M.D., Bricelj V.M., Bauer S.I. 1995. Population biology of the mud crab Dyspanopeus sayi, an important predator of juvenile bay scallops in Long Island (USA) eelgrass beds. J. Shell. Res. 14: 347-357.

Vaz S., ter Hofstede R., Martin J., Dewarumez J.-M., Verin Y., Le Roy D., Heessen H., Daan N. 2007. Benthic invertebrates community structure inferred from bottom trawl hauls observations and its relationships to abiotic conditions in the southern North Sea. ICES Tech. Rep. 'Structure and dynamics of the benthos in ICES waters'CM 2007/A: 03, 21 pp.

Whetstone J.M., Eversole A.G. 1981. Effects of size and temperature on mud crab, Panopeus herbstii, predation on hard clams, Mercenaria mercenaria. Estuaries 4: 153-156.

Williams A.B. 1984. Shrimps, lobsters and crabs of the Atlantic coast of the eastern United States, Maine to Florida. Smithsonian Institution Press, Washington, DC, 550 pp.

Scient. ed.: C. Froglia.

Received February 11, 2011. Accepted June 16, 2011.

Published online December 16, 2011. 